DOI 10.4467/2543733XSSB.17.011.9986

MAGDALENA BŁASZAK

Instytut Filologii Słowiańskiej

Uniwersytet Śląski

\title{
JĘZYK MACEDOŃSKI PO ROZPADZIE JUGOSŁAWII
}

\author{
Macedonian language after the collapse of Yugoslavia
}

\author{
Summary
}

This paper describes the linguistic situation in Macedonia since 1991, after the collapse of Yugoslavia. The situation changed after World War II, when Macedonia became a part of Yugoslavia. According to the cultural autonomy principles, on the 2nd of August 1944, Macedonian language acquired the status of literary language and official language of the Republic of Macedonia. At the time when Macedonia was a part of Yugoslavia, the implementation of various changes, mainly lexical ones, started in Macedonian language. Serbisms were eliminated and replaced with native words in various areas of life. Elements of Serbian language were being removed, while, on the other, due to the technological advances, more and more Anglicisms began to appear in the language. Globalization, technology development and growing importance of media - all these factors caused substantial growth of internationalisms usage in Macedonian language. Macedonian Language Council (Совет за македонски јазик) in the "Strategy for the Development of Culture in Macedonia in 2012-2017", presented an action plan, which, under its leadership, it is to be carried out within a specified period. One of its main tasks is to update the spelling - mainly due to appearance of new terminology in computer science, medicine and technology. Observing the trends of the Macedonian language for the last 20 years, it has been noticed that it is a subject of more general processes similar to those visible in other Slavic languages, however, it also reveals some characteristic phenomena associated with Macedonian language.

Keywords: Macedonian language, codification, language norm, internationalism, word formation

Słowa kluczowe: język macedoński, kodyfikacja, norma językowa, internacjonalizmy, słowotwórstwo

Język macedoński należy do grupy języków południowosłowiańskich. Posługuje się nim ok. 1,8 mln ludzi, głównie mieszkańców Macedonii, ale używany jest także przez 
emigrantów np. w Kanadzie, Australii czy Stanach Zjednoczonych. Ponieważ Macedonię zamieszkują mniejszości narodowe, jej mieszkańcy są użytkownikami także innych języków, zarówno słowiańskich jak i niesłowiańskich. Obecnie język macedoński jest językiem urzędowym Republiki Macedonii, pozostając w koegzystencji na znacznych obszarach jej terytorium z językami albańskim, romskim, arumuńskim, greckim, serbskim i tureckim.

W artykule przedstawię opis sytuacji językowej w Macedonii po rozpadzie Jugosławii, czyli od 1991 roku. W krótkim wstępie nawiążę do długiej i trudnej historii formowania się języka macedońskiego, przybliżając jednocześnie stosunki polityczne między Macedonią a krajami sąsiednimi.

Współczesny język macedoński jest najbardziej spokrewniony z językiem staro-cerkiewno-słowiańskim, co wynika z faktu, iż język staro-cerkiewno-słowiański powstał w oparciu o dialekt Słowian południowych z okolic Salonik i z tej przyczyny jest utożsamiany z językiem staromacedońskim. Mimo tak długiej tradycji standardowy język macedoński jest uważany za jeden z najmłodszych języków słowiańskich ${ }^{1}$. Dzieje się tak dlatego, iż jego kodyfikacja miała miejsce w latach czterdziestych XX wieku, a do tego momentu nie był traktowany jako odrębny język Macedończyków tzw. Macedonii Wardarskiej. Mimo tej kodyfikacji wielu Bułgarów nadal uznaje macedoński za dialekt bułgarski². Także Grecy nie uznają nazwy Macedonii, gdyż dla nich jest to określenie historycznej krainy i obszaru ze stolicą w Salonikach. Po rozpadzie Jugosławii i uzyskaniu niepodległości, Była Socjalistyczna Republika Macedonii zmuszona została do przyjęcia (przejściowej) nazwy państwa - Była Jugosłowiańska Republika Macedonii. Serbowie natomiast uważają że Macedończycy to ,prawie Serbowie” - ze względu na podobny język, religię i alfabet ${ }^{3}$. W ostatnim czasie znów rozgorzała dyskusja na temat konfliktu macedońsko-greckiego, kiedy w styczniu 2018 roku oba państwa uzgodniły powołanie roboczych grup, których zadaniem będzie rozwiązanie trwającego od prawie trzydziestu lat sporu dotyczącego nazwy postjugosłowiańskiej Macedonii. Zapoczątkowany w 1992 roku konflikt skutecznie blokuje macedońskie starania o członkostwo w NATO i Unii Europejskiej. Decyzja o podjęciu prac przez wspomnianą przeze mnie grupę roboczą wywołała protesty wśród ludności greckiej. Istnieją obawy, że używanie nazwy Macedonia może w przyszłości umożliwić wystapienie z roszczeniami terytorialnymi wobec greckiej prowincji o tej nazwie. Na rezultat planowanych prac i ewentualne zakończenie sporu musimy jeszcze poczekać ${ }^{4}$.

Macedończycy z Macedonii Wardarskiej walkę o swój język rozpoczęli już na przełomie XIX i XX wieku, kiedy Krste Misirkov w 1903 roku opublikował w swojej pracy Za makedonckite raboti program macedońskiej polityki językowej. Postulował w nim uniezależnienie się od Bułgarii i Serbii oraz utworzenie macedońskiego języka literackiego opartego na dialektach okolic Prilepu i Bitoli - czyli dokładnie tych, które stanowią podstawę współczesnego literackiego języka macedońskiego.

\footnotetext{
${ }^{1}$ Za najmłodszy był uważany do lat 90. XX w., wówczas Słowiańszczyźnie zaczęło „przybywać” języków, gdyż pojawiły się nowe, skodyfikowane języki - bośniacki (1995), rusińsko-łemkowski i kaszubski (2005) oraz czarnogórski (2007).

${ }^{2}$ Ze względu na złożoność tzw. kwestii macedońsko-bułgarskiej, istniejącą rozległą literaturę na ten temat oraz chronologiczne ramy zakreślone w temacie artykułu nie podejmuję tutaj tej kwestii.

${ }^{3}$ Por. M. Kawka, P. Płaneta, Dyskursy o Macedonii, Kraków 2013, s. 34.

${ }^{4}$ Celem artykułu z oczywistych powodów nie jest ustosunkowanie się do przedstawionej powyżej skomplikowanej sytuacji dotyczącej statusu państwa oraz jego pierwszego języka urzędowego.
} 
W kolejnych latach, po wojnach bałkańskich, Macedonia, należąca ciągle do Imperium Osmańskiego, została podzielona pomiędzy Bułgarię (Macedonia Piryńska), Serbię (Macedonia Wardarska) i Grecję (Macedonia Egejska). Każde z tych państw, zdając sobie sprawę $z$ wagi języka jako podstawowego elementu dla definiowania narodowej tożsamości, tłumiło próby rozwoju języka macedońskiego, wprowadzając do powszechnego użycia odpowiednio bułgarski, serbski i grecki. Odzyskanie wschodnich terenów Macedonii przez Bułgarię podczas II wojny światowej i w konsekwencji wprowadzenie władzy bułgarskiej oraz języka bułgarskiego jako urzędowego spotkało się z rezerwą zamieszkującej ją ludności, która uświadamiała sobie, że są Macedończykami, a nie Bułgarami.

Sytuacja zmieniła się po II wojnie światowej, kiedy Macedonia Wardarska jako autonomiczna republika stała się częścią Jugosławii. Zgodnie z zasadami mówiącymi o autonomii kulturalnej, 2 sierpnia 1944 roku język macedoński uzyskał status języka literackiego i zarazem oficjalnego języka Republiki Macedonii. Miało to miejsce na posiedzeniu $\mathrm{ACHOM}^{5}$. Jako podstawę języka literackiego wybrano zachodnie części dialektów centralnych ${ }^{6}$. W dniu 3 maja 1945 roku przyjęto także macedońską wersję cyrylicy, w której wprowadzono zasadę oddania poszczególnych fonemów za pomocą jednej litery, kodyfikując pisownię o charakterze fonetycznym. Pod tym względem macedońska cyrylica jest bliższa serbskiej cyrylicy niż bułgarskiej. O wpływach serbskiego alfabetu świadczy inwentarz liter i macedońska ortografia - obowiązywanie zasady zapisu fonetycznego oraz obecność w alfabecie macedońskim znaków serbskich takich jak $\_, l b, \mu, j$ przy równoczesnym usunięciu znaków języka staro-cerkiewno-słowiańskiego, obecnych we współczesnym języku bułgarskim opisowe języka macedońskiego, ustalano podstawy normy językowej, opracowywano słownik języka macedońskiego, który ukazał się jako słownik dwujęzyczny: macedońsko-serbsko-chorwacki ${ }^{7}$.

Język macedoński należy do języków tzw. ligi bałkańskiej, dlatego oprócz daleko idącego podobieństwa do języków słowiańskich, zawiera cechy języków zaliczanych do wspomnianej ligi - mianowicie języka bułgarskiego, albańskiego, rumuńskiego, południowo-wschodnich dialektów języka serbskiego i greckiego. Można tutaj wyodrębnić zarówno cechy gramatyczne, jak też wspólną leksykę. Za cechy wspólne dla języków owej ligi bałkańskiej uznaje się przede wszystkim: bezwzględne ograniczenie deklinacji, zanik bezokolicznika, rozbudowany system temporalny, wytworzenie się zjawiska określoności i obecność w języku postpozycyjnego rodzajnika, charakterystyczny sposób stopniowania przymiotników i przysłówków odprzymiotnikowych, tworzenie czasu przyszłego za pomocą czasownika „chcieć” - w języku macedońskim za pomocą nieodmiennego morfemu kontynuującego prasłowiański czasownik - א́e. W zakresie leksyki konsekwencją wpływów obcych języków jest duża liczba zapożyczeń - tureckich, greckich czy romańskich.

\footnotetext{
${ }_{5}^{5}$ АСНОМ - Антифашистичко собрание на народното ослободување на Македонија - Antyfaszystowska Rada Wyzwolenia Narodowego Macedonii - pierwszy rząd macedoński.

${ }^{6}$ Por. M. Kawka, P. Płaneta, Dyskursy o Macedonii, s. 24.

${ }^{7}$ Речник на македонскиот јазик со српскохрватски толкувања, т. I-III, ред. Б. Конески, Детска радост, Скопје 1994.
} 
Po rozpadzie Jugosławii w 1991 roku została uchwalona przez parlament Macedonii Konstytucja Republiki Macedonii ${ }^{8}$. Zawiera ona także informacje na temat języka urzędowego kraju, określając, że jest nim język macedoński. Por.:

\section{Устав на Република Македонија \\ Член 7}

Во Република Македонија службен јазик е македонскиот јазик и неговото кирилско писмо.

Во единиците на локалната самоуправа во кои како мнозинство живеат припадниците на нациионалностите, во службена употреба, покрај македонскиот јазик и кирилското писмо, се и јазикот и писмото на националностите на начин утврден со закон.

Во единиците на локалната самоуправа во кои како значителен број живеат припадниците на националностите, во службена употреба, покрај македонскиот јазик и кирилското писмо, се и јазикот и писмото на националностите, под услови и на начин утврдени со закон.

Artykuł ten zawiera poprawki naniesione w 2001 roku, kiedy to po konflikcie albańskim, w ramach porozumienia zawartego 28 lipca 2001 roku w Ochrydzie, wprowadzono zapis, iż „każdy inny język, którym posługuje się co najmniej 20\% ludności, także jest językiem urzędowym wraz z jego alfabetem”. Zgodnie z tym zapisem w gminach zamieszkałych w dużym stopniu przez Albańczyków wprowadzono język albański jako urzędowy. Por.:

\section{Амандман V}

На целата територија во Република Македонија и во нејзините меѓународни односи службен јазик е македонскиот јазик и неговото кирилско писмо. Друг јазик ито го зборуваат најмалку 20\% од граѓаните, исто така, е службен јазик и неговото писмо, како што е определено со овој член. Личните документи на граѓаните кои зборуваат службен јазик различен од македонскиот јазик, се издаваат на македонски јазик и неговото писмо, како и на тој јазик и неговото писмо во согласност со закон. Кој било граѓанин кој живее во единиците на локалната самоуправа во која најмалку 20\% од граѓаните зборуваат службен јазик различен од македонскиот јазик, во комуникацијата со подрачните единиичи на министерствата, може да употреби кој било од службените јазици и неговото писмо. Подрачните единици надлежни за тие единици на локална самоуправа одговараат на македонски јазик и неговото кирилско писмо, како и на службениот јазик и писмо што го употребува граѓанинот. Секој граѓанин во комуникација со министерствата може да употребува еден од службените јазици и неговото писмо, а министерствата одговараат на македонски јазик и неговото кирилско писмо, како и на службениот јазик и писмото што го употребува граѓанинот. Во органите на државната власт во Република Македонија службен јазик различен од македонскиот јазик, може да се користи во согласност со закон. Во единииите на локалната самоуправа јазикот и писмото што го користат најмалку 20\% од граѓаните е службен јазик, покрај македонскиот јазик и неговото кирилско писмо. За употребата на јазиците и писмата на кои зборуваат помалку од 20\% од граѓаните во единиците на локалната самоуправа, одлучуваат органите на единиците на локалната самоуправа. 2. Со овој амандман се заменува членот 7 од Уставот на Република Македонија.

\footnotetext{
${ }^{8}$ Korzystam z Konstytucji Republiki Macedonii zamieszczonej na stronie internetowej: http://www.sobranie.mk/ustav-na-rm.nspx.
} 
Biorąc pod uwagę, iż Albańczycy stanowią około 25\% ludności Macedonii, w listopadzie 2017 roku parlament Macedonii uchwalił ustawę, która ustanawia język albański jako drugi obok macedońskiego oficjalny język w całym kraju. Ma to na celu ułatwienie mniejszości albańskiej komunikowania się we wszelkiego rodzaju urzędach, szpitalach czy sądach. Ponieważ od tego wydarzenia nie minęło jeszcze dużo czasu, w Konstytucji zamieszczonej na stronie internetowej nadal widnieje zapis podany powyżej, bez wprowadzenia stosownych zmian.

W czasie gdy Macedonia przestała być częścią Jugosławii, rozpoczęto poprzez planowaną politykę językową wdrażanie różnych zmian, głównie o charakterze leksykalnym. W różnych dziedzinach życia zaczęto eliminować serbizmy i zastępować je wyrazami rodzimymi. Możemy tu przywołać choćby terminologię wojskową, w której dotychczas dominowały terminy i zwroty serbsko-chorwackie. Oprócz dziedziny wojskowej, zmieniono także status i zakres użycia języka macedońskiego w mediach. $Z$ jednej strony usuwano elementy języka serbskiego, z drugiej zaś, w związku z intensywnym postępem technologicznym, zmianami w ekonomii i gospodarce, procesami globalizacyjnymi, widocznymi w każdej niemal dziedzinie życia, wzrostem znaczenia mediów - do współczesnego języka macedońskiego zaczęły intensywnie przenikać internacjonalizmy.

Rozpoczęto prace nad słownikiem języka macedońskiego w celu zastąpienia dotychczasowego przestarzałego - trzytomowego - z serbsko-chorwackimi wyjaśnieniami. Prace nad wydaniem Słownika Języka Macedońskiego trwały w Instytucie Języka Macedońskiego „Krste Misirkov” w latach 2003-2014. Pod redakcją K. Koneskiego, S. Velkovskiej i Ž. Cvetkovskiego opublikowano 6 tomów słownika Толковен речник на македонскиот јазик, zawierajacego $w$ sumie około 100000 jednostek leksykalnych.

W okresie gdy Macedonia była jeszcze republiką w ramach Jugosławii, wchodziły do macedońskiego zasobu leksykalnego, podobnie jak i innych języków słowiańskich, różne wyrazy obcego pochodzenia, ale dokonywało się to w większości przypadków nieco odmiennie - przez język - pośrednik, jakim był obowiązujący w SFRJ serbsko-chorwacki/chorwacko-serbski. Po rozpadzie Jugosławii, gdy język macedoński wszedł do użycia we wszystkich sferach życia codziennego, kiedy zwiększyła się liczba czasopism, kanałów radiowych i telewizyjnych, doszło także do szybkiego napływu internacjonalizmów, które przenikały głównie z języka angielskiego. W najnowszej warstwie leksyki spotyka się również, chociaż w mniejszej liczbie, germanizmy oraz zapożyczenia z języka francuskiego.

Ponieważ w tym samym czasie lingwiści zaczęli obawiać się o leksykę języka macedońskiego i jego czystość, w 1998 roku uchwalono Ustawe o używaniu języka macedońskiego (Законот за примена на македонскиот јазик), w której jest mowa o powołaniu Rady Języka Macedońskiego (Совет за македонски јазик) oraz Komisji Egzaminów Lektorskich ${ }^{9}$. Ustawa ta, wychodząc od zasady konstytucyjnej, że język macedoński jest językiem oficjalnym, stanowi w gruncie rzeczy polityczną deklarację, podkreślającą znaczenie języka macedońskiego jako języka większości w państwie i w życiu społecznym (komunikacja), kulturalnym, zwłaszcza jego funkcji literackiej i urzędowej; zawiera także program organizacyjny, którego celem jest ochrona i dbałość o ekspansję języka używa-

\footnotetext{
${ }^{9}$ Wzorcem dla Rady Języka Macedońskiego była powołana w 1996 roku uchwałą Prezydium Polskiej Akademii Nauk Rada Języka Polskiego, działająca początkowo jako Komitet przy Prezydium PAN.
} 
nego przez większość ludności w państwie ${ }^{10}$. W wydawanym przez siebie Biuletynie wspomniana Rada przedstawia własną działalność, w ramach której czuwa nad realizacją rozmaitych projektów naukowych, zapewnia poziom kadry naukowej w szkołach i uczelniach wyższych, koordynuje wszelkie kwestie związane z utrzymywaniem odpowiedniego poziomu literackiego języka macedońskiego. Rada Języka Macedońskiego (Cовеm за македонски јазик) w „Strategii Rozwoju Kultury w Macedonii w latach 2012-2017” przedstawiła plan działań, które pod jej przewodnictwem powinny być wykonane w podanym okresie. Jednym z głównych zadań była aktualizacja ortografii - głównie w związku $\mathrm{z}$ pojawieniem się nowej terminologii $\mathrm{w}$ informatyce, medycynie czy technologii. Nie zakładano jakiejś drastycznej zmiany dotychczasowych zasad pisowni, ale bardziej uwzględnienie zapisu nowych wyrazów, stosowania wielkiej litery czy też poprawnego użycia przyjętych do języka licznych skrótów. Pracownicy MAHY ${ }^{11}$ w swoich planach naukowych mają przygotowanie akademickiej gramatyki opisowej języka macedońskiego, co wiąże się także pośrednio ze stworzeniem elektronicznego korpusu języka macedońskiego. Ma on ogromne znaczenie dla badań lingwistycznych i tworzenia wszelkich słowników - jedno- czy więcej języcznych, zwłaszcza że Macedonia jest bodaj jednym z nielicznych krajów w Europie, który takiego korpusu nie posiada ${ }^{12}$. Ponadto zwrócono uwagę na potrzebę wydania słownika etymologicznego języka macedońskiego. Dużą uwagę zaczęto też przywiązywać do działalności redaktorów, którzy powinni być zatrudniani we wszelkiego rodzaju instytucjach, tak aby rozmaite teksty - publikowane przez czasopisma czy wygłaszane w różnego rodzaju mediach - były przez nich sprawdzane pod względem poprawności językowej. Jednak najpierw, przed przystąpieniem do pracy redaktorzy są zobowiązani do zdania egzaminu zawodowego, przygotowanego na podstawie programu określonego przez Radę Języka Macedońskiego.

Zgodnie z przyjętą strategią na lata 2012-2017 udało się opublikować uzupełnione wydanie zasad ortografii i interpunkcji języka macedońskiego. Nowy Правопис на македонскиот јазик został wydany w 2015 roku. Prace nad nim prowadziło 48 autorów. Dorzucono informacje na temat form liczby mnogiej niektórych wyrazów, zasad pisowni wielką literą i interpunkcji. Największy nacisk położono na transkrypcję i transliterację nazw obcych w stosunku do poprzedniego wydania uzupełniono dane dotyczące 19 kolejnych języków, takich jak na przykład arabski, duński, japoński, węgierski czy holenderski. Końcową część monografii stanowią zasady tworzenia tekstów w obrębie różnych stylów naukowych oraz informacje na temat powszechnie stosowanych znaków korektorskich.

Rada nie sprzeciwia się zapożyczeniom z innych języków, jednak uważa, że jeżeli jest zgoda na włączenie do zasobu leksykalnego jakiegoś wyrazu, to powinien on być przyjmowany w formie łacińskiej lub greckiej, a nie, jak to się zazwyczaj dzieje - wtórnie z języka angielskiego, niemieckiego czy francuskiego, na przykład лиценųа, сентенияа. Pożądane by także było - dla zgodności w systemie akcentowym - aby wyrazy te otrzymały sufiks -иja - nотеничија. Językoznawcy postulują także, aby do języka przenikała tylko forma rzeczownika, natomiast sugeruje się, że wyrazy pochodne powinny być tworzone zgodnie z zasadami i normą języka przyjmującego.

${ }^{10}$ W. Lubaś, Polityka językowa, Opole 2009, s. 404.

${ }^{11}$ МАНУ - Македонска Академија на Науките и Уметностите - Macedońska Akademia Nauk i Sztuk.

${ }^{12}$ Informacja taka jest zamieszczona w Strategii Rozwoju Kultury w Macedonii w latach 2012-2017, której pełny tekst można znaleźć na stronie http://www.kultura.gov.mk/index.php/component/content/category/60. 
Lingwiści, rozumiejąc podejście ekspertów z różnych dziedzin nauki, iż przy standaryzacji terminologii naukowej ważna jest znajomość internacjonalizmów, ostrzegająjednak przed niekontrolowanym przyjmowaniem do języka wszystkich wyrazów. Dlatego ważna jest współpraca pomiędzy lingwistami i specjalistami z innych dziedzin nauki (na przykład ekonomistami, branżą ITI), która zaowocuje stworzeniem solidnego korpusu terminologicznego w danej dziedzinie. Badając terminologię ekonomiczną współczesnego języka macedońskiego, Makarjoska i Georgievska przedstawiły wykaz wyrazów i sposób ich przejęcia z języka angielskiego. Podzieliły je na dwie grupy:

A. Wyrazy w całości przejęte - pochodzenia angielskiego (transkrybowane i nietranskrybowane). Mimo iż wszystkie wyrazy włączane do zasobu leksykalnego języka macedońskiego powinny być transkrybowane zgodnie z zasadami ortografii, zdarza się, że w terminologii ekonomicznej pojawiają się anglicyzmy, dodatkowo zapisywane alfabetem łacińskim. W rezultacie dochodzi do mieszania dwóch alfabetów. Autorki podają też przykłady wyrazów, które mają swój odpowiednik w języku macedońskim, a mimo to używa się anglicyzmu równolegle z thumaczeniem, na przykład: merchandiser - мрчендијзер - трговец.

B. W grupie drugiej znajdują się anglicyzmy przejęte w oryginalnej formie, chociaż istnieje możliwość ich przysposobienia za pomocą rodzimych sufiksów, np. кеш - кешира - кеширање (ang. cash) ${ }^{13}$.

W języku macedońskim często zdarza się sytuacja, że skróty przejęte z języka angielskiego pisane są w sposób zróżnicowany, bez zwracania uwagi na ich charakter. Na przykład skrót ЛИБОР może być zapisywany jak wyżej lub w następujący sposób: либор - Либор. Dochodzą do tego sytuacje, że skrót ten jest używany z rodzajnikiem postpozytywnym, co zgodnie z zasadami jezyka macedońskiego jest błędem ${ }^{14}$. W przypadku zapożyczeń zdarzają się hybrydalne połączenia wyrazowe, złożone $\mathrm{z}$ dwóch anglicyzmów czy też jednego anglicyzmu i jednego latynizmu, kiedy jedna w części jest przetłumaczona, a druga pozostaje w oryginale, na przykład менацерски договор, паричен трансфер.

Nierzadko występują wyrazy błędnie przetłumaczone z języka oryginału, na przykład ang. commission thumaczone jako комисија, zamiast провизија ${ }^{15}$. Anglicyzmy napływaja do terminologii ekonomicznej bardzo szybko i w sposób niekontrolowany, a to skutkuje nieprzestrzeganiem przez użytkowników języka ustalonych zasad ortografii i gramatyki. Tak łatwe przenikanie obcej terminologii do języka macedońskiego spowodowane jest także tym, iż są one uważane za modniejsze i „lepiej brzmiące”, bardziej naukowe i prestiżowe niż wyrazy rodzimego pochodzenia, co niewątpliwie jest przejawem znacznego językowego snobizmu.

Wzbogacanie zasobu słownictwa odbywa się nie tylko przez zapożyczanie wyrazów z innych języków, lecz także wskutek różnych procesów słowotwórczych. Każdy język dysponuje wieloma środkami dla tworzenia nowej leksyki. W języku zachodzą ciągłe zmiany w obrębie wszystkich stylów. Wskutek procesu uniwerbizacji powstają nowe wy-

${ }^{13}$ Por. Л. Макаријоска, Б. Павлеска-Георгиевска, Влијанието на англискиот јазик врз економската терминологија во македонскиот, српскиот и хрватскиот јазик, [в:] Славистички студии 15-16, Универзитет Св. Кирил и Методиј, Скопје 2013, с. 143-144.

${ }^{14}$ Ibidem, s. 145.

${ }^{15}$ Por. Ibidem, s. 149. 
razy, pozwalające na określenie jednym słowem np. pewnej osoby. Możemy tu przywołać liczne przykłady sufiksacji rzeczowników od przymiotników, określających pewną cechę danej osoby, na przykład: веселник-весел човек, чесник-чесен човек, злобник/злобница - злобен човек, злосторник - човек ито прави зло ${ }^{16}$.

W tekstach artystycznych - głównie w poezji - często spotykane są formy złożone z dwóch komponentów - dwóch rzeczowników. Połączone są one w zapisie ortograficznym myślnikiem, np. мигот-сегашност ${ }^{17}$.

Bardzo często spotykane są rzeczowniki motywowane, oznaczające osoby, tworzone

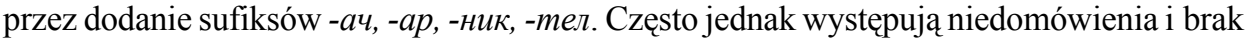
dookreślenia w przypadku nowo powstałych jednostek leksykalnych. Możemy tu przytoczyć przykłady takie jak aymucm - określające nie tyle człowieka chorego na autyzm, lecz osobę, która znajduje się na tzw. „out” - na wylocie. Podobnie вардареu nie jest, zgodnie ze Słownikiem Języka Macedońskiego, określeniem wiatru wiejącego znad Wardaru, lecz członkiem klubu piłkarskiego „Wardar”. Z użycia wychodzi przymiotnik поранешен, zastępowany złożeniami z prefiksem екс-, na przykład ексминистер ${ }^{18}$.

We współczesnej prasie macedońskiej zwiększa się produktywność rzeczowników powstałych od skrótowców, określających członków partii czy różnych organizacji, na przykład НАТО-веи - натовеu. Bardzo dużą frekwencją cechują się wyrazy zawierające prefiksy против- і меѓy- na przykład противзаконски, меѓупартиски. W przypadku czasowników występuje tendencja do tworzenia ich od podstawy rzeczownika z sufiksem -ува - директорува, -ира - политизира ${ }^{19}$.

W ostatnich latach dochodzi do wymiany bardzo frekwentywnego sufiksu -ние na inne, co jest spowodowane uznaniem go za formę archaiczną, która przeniknęła do języka z literatury, i w zasadzie jest formą nieproduktywną. Faktyczną przyczyną tych substytucji jest dążenie do oddalenia słownictwa macedońskiego od bułgarskiego, gdyż rzeczowniki odczasownikowe na -ние są najbardziej typowe dla literackiej bułgarszczyzny, podobnie jak np. w rosyjskim i polskim. Dlatego też w miarę możliwości dąży się do zamiany tego przyrostka, na przykład: состојание - состојба, исклучение - исклучок, решение решавање, владение - владеење; дејание - дејства, објаснение - објаснување $e^{20}$.

W zakresie słowotwórstwa doszło do wielu zmian; obserwuje się zwiększone użycie przyrostka -ба, na przykład настојба, согледба, вражба, делба, женидба, изведба. W przypadku czasowników coraz częściej sufiks -yвa zastępuje używane wcześniej, na przykład одлага - одложува, сопина - сопнува, седина - седнува, легина-легнува, кутина - кутнува.

Bardzo często pojawiającym się sufiksem jest -apa. Według L. G’urkovej przeniknął on do języka macedońskiego jeszcze z języka serbsko-chorwackiego, głównie dla potrzeb

${ }^{16} \mathrm{C}$. Велева, Зборообразувачките тенденции во некои функционални стилови во македонскиот јазик, [в:] Реферати на македонските слависти за XIV-от меѓународен славистички конгрес во Охрид, МАНУ; Скопје 2008, с. 58.

${ }^{17}$ Ibidem s. 59.

${ }^{18}$ Ibidem s. 63

${ }^{19} \mathrm{C}$. Велева, Зборообразувачките тенденции во некои функционални стилови во македонскиот јазик, c. 58 .

${ }^{20}$ С. Велева, Влијанието на надворешнојазичните фактори врз зборообразувачкиот систем во македонскиот јазик, [в:] Македонски социолингвистички и филолошки теми, Совет за македонски јазик на Република Македонија, Скопје 2002, с. 46. 
codziennej komunikacji. Powstałe w ten sposób rzeczowniki zamieniają podobne wyrazy rodzimego pochodzenia, doprowadzając do ich archaizacji, na przykład книжара книжарниия. Sufiks ten jest ciągle produktywny w języku macedońskim, liczne derywaty znajdują się w codziennym użyciu, stosowane są choćby w nazwach firm, na przykład Стаклара-Скопје, Скопска пивара, ale Прилепска пиварница, mimo iż często doprowadzają do pojawiania się form niezgodnych z normą języka macedońskiego, na przykład сокара, палачинкара ${ }^{21}$.

Bardzo produktywny jest prefiksalno-sufiksalny sposób tworzenia przymiotników, na przykład безлебен - без леб / без леб> безлебен. Przymiotniki mogą być też tworzone za pomocą złożeń, na przykład најдигноглав - со најдигната глава / со најдигната глава> најдигноглав ${ }^{22}$.

Także w obrębie przysłówków tworzone są nowe formy poprzez zrośnięcie przyimka z rzeczownikiem, przymiotnikiem, przysłówkiem lub liczebnikiem, na przykład наветер, одсрие, еднаводруга, навнатре, навечер, предвреме.

Dzięki tym modelom słowotwórczym tworzone są środki leksykalne, które, jako tzw. skrzydlate słowa, wchodzą do języka potocznego. Procesy słowotwórcze widoczne są także w stylu publicystycznym, który obejmuje wiele sfer życia codziennego. Za pośrednictwem mediów dociera do odbiorcy nowa leksyka, budowana jest równocześnie określona kultura językowa.

Jeżeli chodzi o turcyzmy w języku macedońskim, to duża ich część występuje współcześnie w jego biernym użyciu - Macedończycy rozumieją je, natomiast sami rzadko wykorzystują w swoich wypowiedziach. Mowa tu głównie o wyrazach używanych w stylu potocznym, określających przedmioty użytku codziennego, np. комиија. Z drugiej strony jednak do języka - głównie do stylu publicystycznego - napływają turcyzmy, będące rezultatem wolności w zakresie wyrażania językowego, na przykład еснаф, урнек. Ciaggle produktywny jest, częściowo nacechowany, sufiks - uuja, dodawany do podstaw różnych wyrazów, na przykład викендција określa posiadacza domku letniskowego, моториија - posiadacza motoru, филмација - osobę pracującą w branży filmowej, водоводиија - hydraulika, ловиија - osobę zajmującą się łowiectwem, трамвајиија - kierowcę tramwaju, meamapuıja - osobę pracującą w branży teatralnej. Widoczne są także znaczne wpływy języka angielskiego, nie tylko na poziomie leksykalnym, ale także na płaszczyźnie syntaktycznej, na przykład zamiast starszego wyrażenia конференција за nечаm coraz częściej używane jest wyrażenie прес конференција - dla określenia konferencji prasowej, скопски цез фестивал - dla nazwy festiwalu jazzowego w Skopiu ${ }^{23}$.

Podobnie na poziomie morfologicznym doszło do różnych zmian w języku macedońskim. Obecnie częściej do tworzenia liczby mnogiej rzeczowników jednosylabowych rodzaju męskiego używa się obok sufiksu -евu także sufiks -oвu, w związku z czym w języku pojawiają się dwie formy liczby mnogiej: клучеви - клучови. Pod wpływem innych

${ }^{21}$ Ibidem, s. 47-48.

${ }^{22} \mathrm{C}$. Велева, Зборообразувачките тенденции во некои функичонални стилови во македонскиот јазик, c. 58 .

23 Л. Минова-ЃГркова, Современи состојби во македонскиот јазик, [в:] Предавања на ХХХІІ меѓународен семинар за македонски јазик, литература и култура, Универзитет Св. Кирил и Методиј, Скопје 2000, с. 82. 
języków, w których często używana jest konstrukcja имам+глаголска придавка, także w języku macedońskim można zaobserwować jej częstsze stosowanie.

W obrębie składni języka macedońskiego zwiększyło się użycie krótkich form zaimkowych dopełnienia dalszego dla określenia przynależności девојка ми, zamiast мојата девојка - co wcześniej mogło być stosowane tylko w przypadku bliskiego pokrewieństwa, na przykład мајка ми ${ }^{24}$.

Coraz częściej w języku macedońskim pojawiają się też derywaty żeńskie od męskich, określające płeć osoby, wyrażające profesję, o której jest mowa, na przykład психијатрка, нотарка, które wcześniej nie były w ten sposób rozróżniane; widać zwiększoną aktywność sufiksów tzw. mocji.

Proces ewolucji języka macedońskiego nadal trwa; tak jak w innych językach słowiańskich, najszybsze zmiany zachodzą w warstwie leksykalnej, co jest spowodowane - tak jak w przypadku innych języków, otwarciem na Europę, utrzymywaniem intensywnych kontaktów międzynarodowych, a nawet sporą liczbą mieszanych małżeństw. Pod wpływem wielu czynników dochodzi do zmian w języku. Pozostaje jednak otwarte pytanie, czy intensywne przenikanie wyrazów obcego pochodzenia wzbogaca zasób słownictwa danego języka, czy też może w pewien sposób prowadzi do zubożenia jego narodowej substancji? Problem ten dotyka wielu innych języków.

Obserwując tendencje rozwojowe języka macedońskiego w ostatnich 20 latach, można zauważyć, że podlega on z jednej strony procesom bardziej ogólnym, podobnym do tych, które obserwuje się w innych językach słowiańskich, z drugiej natomiast przejawia pewne charakterystyczne zjawiska, związane z tym językiem. W ostatnim dwudziestoleciu język macedoński, stosując nowe rozwiązania normatywne (z których część tutaj przedstawiłam) i oddalając się w tym zakresie od normy od języka serbskiego ${ }^{25}$, funkcjonuje jako język większości użytkowników - Macedończyków, którzy traktują go jako język etniczny, wyrażający ich narodową tożsamość. Jednak z narastającą systematycznie liczbą mieszkańców i użytkowników innych, niesłowiańskich języków - przede wszystkim albańskiego i tureckiego, pojawiają się dla niego nowe wyzwania w zakresie polityki językowej. Otwarte na dzisiaj pozostaje także pytanie, czy i w jakim kierunku będą się dokonywać ewentualne wzajemne wpływy w obrębie tych trzech języków, oddziałujące na jego normę.

\section{Bibliografia}

Friedman V., Charakterystyka socjolingwistyczna wspótczesnego języka macedońskiego, [w:] Socjolingwistyka 12-13, Instytut Języka Polskiego PAN, Kraków 1993, s. 183-198.

Kawka M., Płaneta P., Dyskursy o Macedonii, Wydawnictwo Uniwersytetu Jagiellońskiego, Kraków 2013, s. 23-86.

Lubaś W., Polityka językowa, Opolskie Towarzystwo Przyjaciół Nauk, Opole 2009, s. 385-408.

Stawowy-Kawka I., Historia Macedonii, Zakład Narodowy im. Ossolińskich, Wrocław-Warszawa-Kraków 2000.

Stawowy-Kawka I., Problem albański w Republice Macedonii, Prace Komisji Środkowoeuropejskiej PAU, t. IV, Kraków 1996, t. IV, s. 81-93.

\footnotetext{
${ }^{24}$ Ibidem.

${ }^{25}$ Brak jest prac omawiających bezpośrednio tę problematykę, deserbizacja widoczna jest w ustaleniach normatywnych.
} 
Topolińska Z., Praktyczne i teoretyczne plusy późnej standaryzacji (na przykładzie języka macedońskiego), Slavia Meridionalis, 17, Instytut Slawistyki Polskiej Akademii Nauk, Warszawa 2017.

Vidoeski B., Pianka W., Topolińska Z. (red.), Stownik macedońsko-polski i polsko-macedoński, Warszawa-Skopje 1990.

Атанасов П., Изнасилен пуризам и поплава на заемки од интернационалната лексика во македонскиот јазик, [в:] Македонскиот јазик денес, Универзитет Св. Кирил и Методиј, Скопје 2001, c. 37-40.

Велева С., Влијанието на надворешнојазичните фактори врз зборообразувачкиот систем во македонскиот јазик, [в:] Македонски сочиолингвистички и филолошки теми, Совет за македонски јазик на Република Македонија, Скопје 2002, с. 45-50.

Велева С., Зборообразувачките тенденции во некои функиионални стилови во македонскиот јазик, [в:] Реферати на македонските слависти за XIV-от мегуународен славистички конгрес во Охрид, МАНУ; Скопје 2008, с. 57-67.

Велјановска К., За новите скратеници во македонскиот јазик, [в:] Зборник во чест на проф. д-р Кирил Конески по повод 80 години од раѓањето, Универзитет Св. Кирил и Методиј, Скопје 2009, с. 27-29.

Веновска-Антевска С., Тенденциите во развитокот на македонскиот јазик, [в:] Tożsamość narodowa $w$ społeczeństwie multietnicznym Macedonii, red. Kawka M., Stawowy-Kawka I., Wydawnictwo Uniwersytetu Jagiellońskiego, Kraków 2008, s. 175-181.

Груевска-Маџоска С., Современи случувања во македонскиот јазик од соииолингвистички аспект, [в:] Меѓународен македонистички собир, Универзитет Св. Кирил и Методиј, Скопје 2010, с. $83-87$.

Конески К. (ред.), Толковен речник на македонскиот јазик, Скопје 2011.

Макаријоска Л., Павлеска-Георгиевска Б., Влијанието на англискиот јазик врз економската терминологија во македонскиот, српскиот и хрватскиот јазик, [в:] Славистички студии 15-16, Универзитет Св. Кирил и Методиј, Скопје 2013, с. 141-151.

Минова-Гууркова Л., Лексиката, нормата и јазично планирање, [в:] Норма и речник, Универзитет Св. Кирил и Методиј, Скопје 2002.

Минова-Ѓуркова Л., Македонскиот јазик денес, [в:] Македонскиот јазик денес, Универзитет Св. Кирил и Методиј, Скопје 2001, с.7-20.

Минова-Гуркова Л., Современи состојби во македонскиот јазик, [в:] Предавања на ХХХІІ меѓ'ународен семинар за македонски јазик, литература и култура, Универзитет Св. Кирил и Методиј, Скопје 2000, с. 69-84.

Спасов Љ., Разликите и сличностите во процесот на стандаризаџија меѓу бугарскиот, српскиот и македонскиот јазик, [в:] Предавања на ХХХІІІ меѓународен семинар за македонски јазик, литература и култура, Универзитет Св. Кирил и Методиј, Скопје 2001, c. $71-84$.

Цветковски Ж., Морфологијата и стандардојазичната норма, [в:] Македонскиот јазик денес, Универзитет Св. Кирил и Методиј, Скопје 2001, с. 25-30.

Цветковски Ж. (ред.), Правопис на македонскиот јазик, Скопје 2015.

Magdalena Błaszak, doktor nauk humanistycznych, adiunkt w Zakładzie Badań Kontrastywnych i Glottodydaktyki w Instytucie Filologii Słowiańskiej Uniwersytetu Śląskiego w Katowicach. Jej zainteresowania skupiają się wokó językoznawstwa synchronicznego, badań konfrontatywnych w obrębie pragmalingwistyki i struktury tekstu, a także wokół zagadnień z zakresu socjolingwistyki oraz normy i uzusu społecznego języków południowosłowiańskich. Autorka monografii Imperceptywność w języku macedońskim i polskim (2014). 